\title{
Kepuasan Kerja dan Prediktornya pada Pegawai Negeri Sipil
}

\author{
Aqidatul Izza' ${ }^{1}$, Soffy Balgies ${ }^{1}$ \\ 1Fakultas Psikologi dan Kesehatan UIN Sunan Ampel Surabaya
}

DOI: http://doi.org/10.29080/jpp.v12i2.623

\begin{abstract}
Job satisfaction can make an organization or company realize its expectations. This research aims to study the relationship between self-efficacy, work engagement, and job satisfaction among government employees at UIN Sunan Ampel Surabaya. Having purposive sampling technique, there is 92 government employee of UIN Sunan Ampel Surabaya who was involved in this correlational quantitative research. Data were analyzed using multiple regression. The results showed that selfefficacy and work engagement was related to job satisfaction either. The value of self-efficacy and work engagement to job satisfaction shows the contribution of the two variables to job satisfaction. The positive relationship between the variables of self-efficacy, work engagement, and job satisfaction also illustrates that the higher the self-efficacy, the higher the perceived job satisfaction. Besides, the more individuals engage in their work the more satisfied they will be with their work.
\end{abstract}

Kata kunci : self efficacy, work engagement, job satisfaction

\begin{abstract}
Abstrak : Job satisfaction menjadikan organisasi atau perusahaan dapat mewujudkan harapanya. Penelitian ini bertujuan untuk mengetahui hubungan self efficacy, work engagement dengan job satisfaction pada pegawai Negeri UIN Sunan Ampel Surabaya. Sebanyak 92 pegawai negeri sipil UIN Sunan Ampel Surabaya yang diambil menggunakan purposive technique sampling dilibatkan dalam penelitan kuantitatif korelasional ini. Selanjutnya teknik analisa data menggunakan regresi ganda. Hasil penelitian menunjukkan self efficacy dan work engagement berhubungan dengan job satisfaction baik secara bersama-sama maupun parsial. Nilai sumbangan efektif dari self-efficacy dan work engagement terhadap kepuasan kerja menunjukkan kontribusi kedua variabel dalam membentuk job satisfaction. Hubungan yang positif antara variabel self efficacy, work engagement dengan job satisfaction juga menggambarkan bahwa semakin tinggi self-efficacy yang dimiliki akan semakin meningkatkan job satisfaction yang dirasakan. Demikian pula dengan work engagement yang menunjukkan semakin individu terlihat dalam pekerjaanya maka mereka juga akan merasakan kepuasan dalam bekerjanya.
\end{abstract}

Kata kunci : self efficacy, work engagement, kepuasan kerja

Corresponding Author: Aqidatul Izza (e-mail: aqidatuli840@gmail.com) Program Studi Psikologi Fakultas Psikologi dan Kesehatan UIN Sunan Ampel Surabaya, Jl. A. Yani 117 Surabaya Jawa Timur, Indonesia 60237 


\section{Pendahuluan}

Kepuasan kerja merupakan emosi positif yang dirasakan oleh pekerja setelah melalui sebuah pengalaman kerja (Locke, 1976, Damayanti, 2015). Jika kepuasan kerja tidak mendapatkan perhatian maka akan menimbulkan performa kerja yang tidak baik, rasa bosan, malas, gangguan fisik, anxiety, depresi serta perilaku kontra produktif (Hastuti dan Farid, 2015. Kepuasan kerja dapat dipengaruhi oleh faktor intrinsik dan ekstrinsik. Faktor intrinsik berasal dari dalam diri pegawai sebelum ia mulai bekerja sedangkan faktor ekstrinsik merupakan faktor yang muncul dari lingkungan luar seperti kondisi lingkungan, interaksi antar pegawai, system gaji, waktu kerja, dan lain sebagainya (Rivai,2008).

Kepuasan kerja pada pegawai negeri sipil menjadi tema yang banyak dijadikan bahan penelitian. Penelitian Arrizal (2017) menunjukkan pegawai negeri sipil secara umum memiliki kepuasan kerja yang baik. Hasil survei jobplanet juga memberikan gambaran tentang pegawai negeri sipil di Indonesia saat ini memiliki kepuasan kerja paling tinggi dibandingkan dengan pegawai kerja lainya karena adanya dana pensiun sebagai jaminan hari tua (kompas tahun 2016). Selain itu persaingan yang ketat dalam mendapatkan posisi pekerjaan juga menjadi kebanggan tersendiri bagi mereka yang bisa lolos dalam proses penerimaan.

Penelitian Ardiani dan Mulyana (2018) menunjukkan adanya hubungan antara efikasi diri dengan kepuasan kerja dimana semakin tinggi efikasi diri yang dimiliki maka semakin tinggi pula kepuasan kerja karyawan. Pada seting pegawai negeri, memiliki efikasi diri yang tinggi diharapkan kepuasan kerja yang dimiliki juga akan tinggi sehingga organisasi dapat mencapai tujuanya bersama. Efikasi diri merupakan keyakinan individu terhadap kemampuanya untuk menghadapi segala situasi yang ada dengan menggunakan kemampuan yang dimiliki seberapapun besarnya (Bandura,1997). Ada tiga dimensi utama dalam efikasi diri yaitu level yang berhubungan dengan level tugas individu saat melakukan pekerjaanya, strenght yaitu kekuatan dari keyakinan diri terhadap kemampuan, dan generality yang berhubungan dengan bagaimana tingkah laku individu dalam meyakini kemampuanya. Dewi dan Dewi (2015) dalam penelitiannya juga menunjukkan hasil yang signifikan pada hubungan self efficacy dengan kepuasan kerja. Penelitian Yakin dan Edril (2012) juga menjelaskan bahwa self efficacy mempunyai hubungan yang signifikan dengan kepuasan kerja.

Selain self efficacy, keterikatan pegawai dengan pekerjaanya juga memiliki keterkaitan dengan kepuasan kerja karyawan. Hasil penelitian Cahyani dan Qomariyah (2019) menunjukkan bahwa adanya pengaruh yang signifikan antara terhadap kepuasan kerja. Karyawan yang memiliki keterikatan dengan pekerjaanya akan menunjukkan sikap antusias terhadap pekerjaan dan organisasi tempat mereka bekerja (Robertson, 2010). Penelitian. Work engagement memiliki tiga dimensi yaitu vigor, dedication, dan absorpsi. Vigor menggambarkan adanya level energi yang tinggi dan resiliensi kemauan untuk berusaha, serta gigih dalam menghadapi kesulitan. Dedication merupakan perasaan penuh bermakna yang diiringi dengan adanya antusias, inspirasi, perasaan tertantang, dan bangga terhadap pekerjaanya. Absorpsi adalah konsentrasi individu secara penuh terhadap pekerjaanya sehingga sulit untuk memisahkan diri dengan pekerjaan ( Scaufeli \& Bakker, 2004).

Fenomena lemahnya kepuasaan kerja di kalangan pegawai negeri sipil menunjukkan pentingnya penelitian selanjutnya untuk melihat apa yang dapat membantu meningkatkan kepuasan kerja mereka. Dwitya, Wicaksono, dan karyanta (2016) mengatakan penting untuk melihat lebih jauh bagaimana keterikatan individu secara fisik, kognitif, dan emosional dalam pekerjaanya. Berdasarkan kajian teoritis yang sudah dipaparkan di atas maka penelitian ini bertujuan untuk menguji hubungan antara self 
efficacy, work engagement dengan job satisfaction pada subjek pegawai negeri sipil yang ada di Universitas Islam Negeri Sunan Ampel Surabaya.

\section{Metode Penelitian}

Penelitian ini menggunakan kuantitatif korelasional untuk melihat hubungan self-efficacy dan work engagement dengan job satisfaction. Subjek penelitian ini adalah pegawai negeri sipil UIN Sunan Ampel Surabaya sebanyak 92 orang. Teknik pengambilan sample yang digunakan adalah purposive sampling dengan kriteria tertentu memiliki masa kerja lebih dari 2 tahun dan dan sudah berstatus sebagai pegawi negeri sipil di UIN Sunan Ampel Surabaya.

Alat ukur yang digunakan dalam penelitian ini adalah skala self efficacy yang mengacu pada aspek efikasi diri menurut Bandura (1997) dan skala work engagement menggunakan aspek dari Shaufeli dan Bakker (2004). Selanjutnya skala job satisfaction menggunakan aspek Jewell dan Siegall (1998). Data yang sudah terkumpul, kemudian diolah secara kuantitatif menggunakan teknik korelasi regresi linier ganda.

\section{Hasil Penelitian}

Sebelumnya data harus diuji asumsi dasar terlebih dahulu yang terdiri dari uji normalitas, uji heterokedaktisitas, dan uji multikolinieritas. Dari hasil uji normalitas ketiga variabel self-efficacy, work engagement dan job satisfaction memiliki data berdistribusi normal normal (sig 0,819>0,05). Adapun hasil uji heterokedaktisitas juga menunjukkan tidak terjadi heterokedaktisitas (self efficacy $0.329>0,05$; dan work engagement $0,088>0,05$ ). Uji multikolinieritas menunjukkan dari kedua variabel self efficacy dan work engagement tidak menunjukkan terjadinya multikolinieritas (VIF sebesar $1,661<10,00$ )

Data diskriptif menunjukkan kategorisasi data dibagi menjadi tiga, yaitu kategori rendah, sedang, dan tinggi. Berikut adalah hasil dari kategorisasi data yang dapat dilihat pada tabel dibawah ini.

Tabel 1.

Hasil Uji Kategorisasi Data Tiap Variabel

\begin{tabular}{lccc}
\hline Variabel & Kategori & Jumlah & \% \\
\hline \multirow{3}{*}{ Self Efficacy } & rendah & 27 & $29,3 \%$ \\
& sedang & 31 & $33,7 \%$ \\
\cline { 2 - 4 } & tinggi & 34 & $37,0 \%$ \\
\cline { 2 - 4 } & rendah & 92 & $100,0 \%$ \\
\cline { 2 - 4 } Work Engagement & sedang & 13 & $14,1 \%$ \\
\cline { 2 - 4 } & tinggi & 45 & $48,9 \%$ \\
\cline { 2 - 4 } & & 34 & $37,0 \%$ \\
\hline \multirow{3}{*}{ Job Satisfaction } & rendah & 92 & $100,0 \%$ \\
& & 4 & $4,3 \%$ \\
\cline { 2 - 4 } & sedang & 41 & $44,6 \%$ \\
\cline { 2 - 4 } & tinggi & $47,1 \%$ \\
\cline { 2 - 4 } & & 92 & $100,0 \%$ \\
\hline
\end{tabular}

Hasil uji kategorisasi menunjukkan bahwa 29,3\% pegawai tergolong dalam kategori rendah, 33,7\% pegawai dalam kategori sedang, dan 37,0\% pegawai dalam kategori tinggi. Sedangkan pada variabel work engagement terdapat 14,1\% pegawai tergolong dalam kategori rendah, 48,9\% dalam kategori sedang, dan 37,0\% dalam 
kategori tinggi. Pada variabel job satisfaction terdapat 4,3\% pegawai memiliki kategori rendah, 44,6\% pegawai dalam kategori sedang, dan 51,1\% pegawai dalam kategori tinggi.

Tabel 2.

Tabulasi Silang Self efficacy dengan Job Saftisfaction

\begin{tabular}{clcccc}
\hline \multicolumn{5}{c}{ Job satisfaction } \\
\hline \multirow{3}{*}{$\begin{array}{c}\text { Self } \\
\text { efficacy }\end{array}$} & Rendah & Rendah & Sedang & Tinggi & Total \\
\cline { 2 - 6 } & Sedang & $4(4,3 \%)$ & $21(22,8 \%)$ & $2(2,2 \%)$ & $27(29,3 \%)$ \\
\cline { 2 - 6 } & Tinggi & $0(0 \%)$ & $13(14,1 \%)$ & $18(19,6 \%)$ & $31(33,7 \%)$ \\
\cline { 2 - 6 } & Total & $0(0 \%)$ & $7(7,6 \%)$ & $27(29,3 \%)$ & $34(37,0 \%)$ \\
\hline
\end{tabular}

Selanjutnya adalah hasil tabulasi silang antara self efficacy dengan job satisfaction. Dari data tabel terlihat bahwa mayoritas subjek memiliki self-efficacy yang tinggi dan job satisfaction yang tinggi pula.

Tabel 3.

Hasil Tabulasi Data Work Engagement dengan Job Satisfaction

\begin{tabular}{cccccc}
\hline & \multicolumn{5}{c}{ Job satisfaction } \\
\hline \multirow{3}{*}{$\begin{array}{c}\text { Work } \\
\text { engagement }\end{array}$} & Rendah & $4(4,3 \%)$ & $5(5,4 \%)$ & $4(4,3 \%)$ & $13(14,31 \%)$ \\
\cline { 2 - 6 } & Sedang & $0(0 \%)$ & $26(28,3 \%)$ & $19(20,7 \%)$ & $45(48,9 \%)$ \\
\cline { 2 - 6 } & Tinggi & $0(0 \%)$ & $10(10,9 \%)$ & $24(26,1 \%)$ & $34(37,0 \%)$ \\
\cline { 2 - 6 } & Total & $4(4,3 \%)$ & $41(44,6 \%)$ & $47(51,1 \%)$ & $92(100 \%)$ \\
\hline
\end{tabular}

Hasil uji tabulasi kedua adalah diskriptif antara variabel work engagement dengan job satisfaction. Dari tabel 3 di atas terlihat bahwa pegawai negeri UIN Sunan Ampel Surabaya memiliki work engagement dalam kondisi baik, dengan paling banyak bereda dikategori sedang, selanjutnya ada pada kategori tinggi. Pada kategori work engagement sedang dengan job satisfaction sedang terdapat $28,3 \%$ pegawai, $26,1 \%$ pada kategori work engagement tinggi dengan job satisfaction tinggi.

Hasil uji analisis berikutnya adalah uji hipotesis dengan menggunakan analisis korelasi berganda. Dengan melihat nilai F hitung, dan nilai signifikansi, maka nilai korelasi antar variable adalah sebagai berikut.

Tabel 4.

Hasil Uji F

\begin{tabular}{cccccc}
\hline Model & Sum of Squares & Df & Mean Square & F & Sig. \\
\hline Regression & 790.925 & 2 & 395.462 & 32.561 & .000 \\
\hline Residual & 1080.934 & 89 & 12.145 & & \\
\hline Total & 1871.859 & 91 & & & \\
\hline
\end{tabular}

Nilai F-hitung adalah sebesar 32.561 dengan signifikansi $0,000<0,05$. Hasil ini menunjukkan bahwa variabel self efficacy dan work engagement secara simultan memiliki hubungan dengan variabel job satisfaction. 
Selanjutnya, terdapat hasil uji $\mathrm{T}$ yang digunakan untuk mengetahui hubungan antar variabel self efficacy dan work engagement dengan job satisfaction. Hasil dapat dilihat pada tabel sebagai berikut:

Tabel 5.

\section{Hasil Uji T}

\begin{tabular}{|c|c|c|c|c|c|}
\hline \multirow[t]{2}{*}{ Model } & \multicolumn{2}{|c|}{$\begin{array}{l}\text { Unstandardized } \\
\text { Coefficients }\end{array}$} & \multirow{2}{*}{$\begin{array}{l}\text { Standardized } \\
\text { Coefficients } \\
\text { Beta }\end{array}$} & \multirow[b]{2}{*}{$\mathbf{t}$} & \multirow[b]{2}{*}{ Sig. } \\
\hline & B & Std. Error & & & \\
\hline (Constant) & 8.903 & 3.725 & & 2.390 & .019 \\
\hline Self Efficacy & .601 & .147 & .426 & 5.099 & .000 \\
\hline Work Engagement & .362 & .129 & .291 & 2.807 & .006 \\
\hline
\end{tabular}

Hasil dari uji T menunjukkan hubungan secara parsial antara variabel self efficacy dengan job satisfaction dengan nilai korelasi sebesar 5,099 korelasi dan nilai signifikansi $0,000<0,05$. Hal ini menunjukkan bahwa secara parsial terdapat hubungan antara self efficacy dengan job satisfaction. Selanjutnya, terdapat koefisien korelasi sebesar 2,807 antara variabel work engagement dengan job satisfaction dengan taraf signifikan sebesar $0,006<0,05$. Nilai korelasi menunjukkan hubungan yang signifikan antara variabel work enagagement dengan job satisfaction.

Hasil analisis terakhir digunakan untuk menunjukkan seberapa besar pengaruh antara variabel self efficacy dan work engagement dengan job satisfaction. Berikut adalah hasil koefisien determinasi:

Tabel 6.

Hasil Koefisien Determinasi

\begin{tabular}{clccc}
\hline Model & R & R.Square & $\begin{array}{c}\text { Adjusted R } \\
\text { Square }\end{array}$ & $\begin{array}{c}\text { Std. Error of the } \\
\text { Estimate }\end{array}$ \\
\hline 1 & $.650^{\mathrm{a}}$ & .423 & .410 & 3.48501 \\
\hline
\end{tabular}

Berdasarkan hasil tabel 9 didapatkan hasil $\mathrm{R}$ square sebesar 0,423 yang menunjukkan bahwa kedua variabel bebas self efficacy dan work engagement menyumbang sebesar $42,3 \%$ terhadap job satisfaction dan sisanya 57,7\% adalah kontribusi dari variabel lainya.

\section{Pembahasan}

Hasil analisis regresi linier berganda yang telah dipaparkan pada hasil penelitian menunjukkan hubungan yang signifikan antara self efficacy dengan job satisfaction. Self-efficacy terlihat berhubungan secara positif dan signifikan dengan job satisfaction, dimana semakin tinggi self-efficacy yan dimiliki maka akan semakin tinggi juga job satisfaction. Hal itu sejalan dengan hasil penelitian Yakin dan Edril (2012) yang mengatakan bahwa self-efficacy secara signifikan memiliki hubungan dengan kepuasan kerja. Penelitian Ardiani \& Mulyana (2018) juga menunjukkan korelasi antara self-efficacy dengan job satisfation. Adanya gambaran hubungan self-efficacy terhadap job satisfaction menunjukkan bahwa self-efficacy menjadi salah satu faktor intrinsik yang mempengaruhi job satisfaction.

Self-efficacy merupakan kepercayaan dan keyakinan individu terhadap kemampuan diri untuk mengatur dan melakukan tindakan untuk mencapai sebuah hasil usaha (Bandura, 1997). Dari penjelasan tersebut terlihat bahwa jika individu memiliki self-efficacy tinggi maka mereka juga akan memiliki nilai positif seperti adanya kepercayaan diri, yakin terhadap keberhasilan dan mencapai suatu kepuasan. Sebaliknya 
jika individu memiliki self-efficacy rendah maka akan berdampak negatif pada dirinya, seperti rendahnya keyakinan diri, mudah putus asa, dan mendapatkan hasil yang tidak memuaskan dari usahanya.

Hasil dari kategori data tiap variabel terdapat 37\% pegawai yang memiliki self-efficacy tinggi, 33,7\% dalam kategori sedang dan 4,3\% rendah. Hal ini menunjukkan bahwa self-efficacy yang dimiliki pegawai UIN Sunan Ampel Surabaya tergolong baik. Menurut Bandura (1997) individu dengan self-efficacy tinggi akan mencapai kinerja yang lebih baik, karena mereka memiliki motivasi kuat, tujuan jelas, dan kemampuan untuk sukses. Dengan adanya self-efficacy yang tinggi maka, job satisfaction pegawai juga akan meningkat. Hasil tabulasi silang antara self-efficacy tinggi dengan job satisfaction tinggi ada 29,3\%, kategori self-efficacy sedang dengan job satisfaction sedang terdapat 14,1\%, sedangkan pada kategori self-efficacy rendah dengan job satisfaction rendah hanya terdapat 4,3\% pegawai. Hasil diskriptif tabulasi silang menunjukkan bahwa semakin tinggi self-efficacy pegawai maka akan semakin tinggi juga tingkat job satisfaction pegawai. Hal itu juga ditunjukkan oleh penelitian oleh Purnama \& Manuati (2015) dimana semakin tinggi self-efficacy semakin tinggi juga job satisfaction yang dirasakan.

Analisis regresi linier berganda berikutnya adalah variabel work engagement dengan job satisfaction yang juga didapatkan hasil koefisien korelasi yang signifikan. Dari hasil tersebut terlihat adanya hubungan yang signifikan antara work engagement dan job satisfaction. Hasil ini sejalan dengan penelitian Cahyani dan Qomariyah (2019) yang menunjukkan work engagement memiliki pengaruh terhadap job satisfaction. Work engagement yang tertanam dalam diri individu adalah salah suatu energi positif, ketahanan mental dan fisik dari pekerjaan, sehingga dari adanya hal tersebut muncul job satisfaction yang baik pula. Menurut Kuntari (2015) karyawan yang terikat adalah mereka yang memiliki keterikatan dalam hal kognitif, fisik dan emosial dengan pekerjaanya. Salah satu faktor internal dari work engagement yang berhubungan dengan job satisfaction adalah faktor dedikasi, dimana faktor ini berhubungan dengan faktor psikologis dari job satisfaction. Ketika inividu memiliki pemikiran antusisas dalam pekerjaanya, maka akan berdampak pada psikologisnya, sehingga kedua aspek tersebut dapat berhubungan. Park dan Gursoy (2012) menjelaskan ketika karyawan sudah terikat dengan pekerjaan, maka berdampak pada karakter psikologis, yang dapat mendorong kepuasan kerjanya.

Hasil kategori data work engagement menunjukkan bahwa terdapat 37\% pegawai yang tergolong dalam kategori tinggi, 48,9\% pegawai dalam kategori sedang, dan 14,1\% dalam kategori rendah. Dari hasil ini menujukkan bahwa secara umum pegawai UIN Sunan Ampel Surabaya memiliki work engagement yang baik, dengan hasil terbanyak terdapat pada kategori sedang. Apabila pegawai tidak memiliki work engagement yang baik maka job satisfaction yang dimiliki pegawai akan rendah. Kreitner dan Kinicki (2005) menegaskan ketika karyawan merasa tidak puas maka itu akan membuat mereka tidak memiliki komitmen kerja, motivasi, dan ikatan dengan pekerjaan yang dilakukan.

Hasil dari tabulasi silang antara work engagement dengan job satisfaction menunjukkan bahwa terdapat $28,3 \%$ pegawai yang berada pada kategori work engagement sedang dengan job satisfaction yang sedang. Sebanyak 20,7\% pegawai memiliki work engagement sedang dengan job satisfaction tinggi, 26,1\% pegawai memiliki work engagement tinggi dengan job satisfaction tinggi dan 4,3\% pegawai yang memiliki work engagement rendah dengan job satisfaction tinggi. Dari hasil tersebut dapat dilihat bahwa ketika work engagemet yang dimiliki pegawai tinggi, maka job satisfaction yang dimiliki pegawai juga akan tinggi. Hasil penelitian Moura, Ramos \& Jesus (2015) juga menunjukkan hubungan positif dan signifikan antara work engagement dengan job satisfaction. Work engagement yang tinggi akan membuat job satsiafction juga tinggi.

Hasil uji analisis regresi linier berganda menunjukkan bahwa secara simultan ada hubungan antara self-efficacy, work engagement dengan job satisfaction. Hasil temuan itu sejalan dengan penelitian Helena dan Harsa (2019) yang mengatakan bahwa self-efficacy 
dan work engagement bersama-sama berhubungan dengan job satisfaction. Self-efficacy dan work engagement memiliki pengaruh positif terhadap kepuasan kerja dengan adanya keterlibatan yang timbal balik dari waktu ke waktu. Selain itu koefisien determinasi sebesar 42,3\% menunjukkan besar pengaruh kedua variabel terhadap job satisfaction sedangkan sisanya dapat dipengaruhi oleh faktor lainya. Adanya kontribusi kedua variabel yaitu self-efficacy dan work engagement ini akan menimbulkan kepuasan kerja yang baik. Hal itu sejalan dengan yang dikayakan Lent dan Brown (2006) dimana keyakian diri dapat menumbuhkan pengalaman kepuasan melalui keterikatan kerja dalam aktivitas yang diarahkan pada suatau tujuan. Adanya job satisfaction dalam diri pegawai akan menjadikan mereka tetap tinggal pada organisasi tersebut. Dari hasil kategori data pada job satisfaction didapatkan nilai paling tinggi sebesar $51,1 \%$ pegawai puas dengan pekerjaanya, dan $44,6 \%$ pegawai berada pada posisi kategori dengan job satisfaction sedang. Hal ini menunjukkan bahwa job satisfaction yang dimiliki oleh pegawai negeri sipil UIN Sunan Ampel cukup tinggi.

\section{Simpulan dan Saran}

Penelitian ini menunjukkan adanya hubungan antara self-efficacy dan work engagement dengan job satisfaction pada pegawai negeri sipil UIN Sunan Ampel Surabaya. Semakin tinggi self-efficacy yang dimiliki pegawai semakin tinggi pula nilai kepuasan terhadap pekerjaan yang dirasakan. Selanjutnya semakin kuat work engagement yang dimiliki akan juga membuat pegawai semakin bertahan pada tempat mereka bekerja karena merasakan keterikana yang kuat dan puas dengan pencapaian yang ada. Selanjutnya dengan self-efficacy dan work engagement yang dimiliki akan membuat kepuasaan dalam bekerja akan semakin meningkat. Penelitian ini masih memiliki kekurangan dalam pelaksanaan penelitian, sehingga diharapkan pada penelitian selanjutnya dapat memperluas populasi yang akan diteliti. Selain itu msih banyak faktor-faktor lain yang dapat mempengaruhi kepuasan kerja sehingga peneliti selanjutnya dapat menggunakan variabel bebas lain untuk diteliti.

\section{Daftar Pustaka}

Ardiani \& Mulyana. (2018). Hubungan Antara Efikasi Diri Dengan Kepuasan Kerja Pada Karyawan Bank Pembiayaan Rakyat Syariah. Jurnal penelitian Psikologi vol.5 no.2.

Arrizal, Arrizal. (2017),Analsis kepuasan kerja pegawai negeri sipil: kasus organisasi pemerintahan X. Padang: Universitas Andalas; diunduh 15 oktober 2021. Tersedia pada: http://repo.unand.ac.id/5028/

Bandura, A.(1997) Self-Efficacy: The Exercise Of Control. New York. W.H. Freeman.

Cahyani \& Qomariyah.(2019). Peran work engagement terhadap kepuasan kerja pada karyawan pelayanan kefarmasian dirumah sakit. jurnal psikologi Vol.12. no.1.

Damayanti, Elok. (2017). Pengaruh Role Stressor Dan Persepsi Dukungan Organisasi Terhadap Kepuasan Kerja Dan Komitmen Organisasi Di Universitas Narotama. Jurnal spirit pro patria, (03). 96-101

Dewi, Putu Eka.P., Dewi, I Gusti Ayu.M. (2015). Pengaruh Self-Efficacy Dan Motivasi Kerja Pada Kepuasan Kerja Karyawan Happy Bali Tour \& Travel Denpasar. Jurnal Manajemen, Strategi Bisnis dan Kewirausahaan 9(01) 15-25.

Dwitya M, Wicaksono B, \& Karyanta NA. (2016). Hubungan antara keadilan organisasi dan keterikatan karyawan dengan kepuasan kerj pada karyawan PT. Mekar Armada Jaya Magelang. Jurnal wacana psikologi 8(1) 1-12.

Hastuti, W, dan Farid,M. (2015). Motivasi Kerja, Internal Locus Of Control dan Kepuasan Kerja Pada Karyawan Bagian Marketing Dan Supporting di PT X Cabang Surabaya. Jurnal Psikologi Indonesia4(02),197-207 
Helena \& Harsha. (2019). Relations Among Teachers' Self-Efficacy Beliefs, Engagement, And Work Satisfaction:A Social Cognitive View. Journal contempory psychology Vol.58 75-84.

Jewell, L.N \&Siegal, M. (1998). psikologi industry atau organisasi modern. Ahli bahasa: Pudjaatmaka, A.H \&Meitasari. Arcan:Jakarta.

Kuntari,R. (2015). Hubungan Work-Family Enrichment dengan Work Engagement Pada Perawat Wanita. Jurnal Psikologi Ulayat, 2(1), 37-40

Kreitner R, \& Kinicki, A. (2005). Perilaku organisasi. Buku 1, edisi kelima. Salemba empat: Jakarta Lent, R. W., \& Brown, S. D. (2006). Integrating person and situation perspectives on work satisfaction: A social-cognitive view. Journal of Vocational Behavior, 69, 236-247.

Locke, E.A. (1976). The Nature And Causes Of Job Satisfaction, Newyork: John Wiley And Sons.

Moura,D., Ramos, A., dan Jesus, S. (2015). Psychological empowerment and work engagement as predictors of work satisfaction: a sample of hotel employess. International jurnal of sapital and organizational dynamics 3(2).

Park, J., Dan D. Gursoy. (2012). Generation Effects On Work Engagement Among US Hotel Employees. Internation Journal Of Hospitality Mangement, 11951202.

Ramadhan, Dimas Maulana. (2020). Hubungan Antara Work Engagement Dan Kepuasan Kerja Pada Pegawai Negeri Sipil Dengan Dukungan Sosial Sebagai Variabel Moderator. Skripsi. Yogyakarta: Universitas Islam Indonesia.

Pratama, Galih Dian (2018) Hubungan Antara Self Efficacy Dengan Kepuasan Kerja Pada Karyawan Pt. Kusuma Sandang Mekarjaya Yogyakarta. Skripsi Thesis, Universitas Mercu Buana Yogyakarta.

Purnama dan Manuati. (2015). Pengaruh Self Efficacy Dan Motivasi Kerja Pada Kepuasan Kerja Karyawan Happy Bali Tpur \& Travel Denpasar. Jurnal manajemen, strategi bisnis dan kewirausahaan, 9 (01).

Robertson dan Coper (2010). Full engagement: the integration of employee engagement and psychological wel-being. SA journal of industrial psychology no.34 vol.3.

Salatina, Novi Idris, dan Mubarak, Ali. (2016). Hubungan Employee Engagement dengan Kepuasan Kerja pada Karyawan Gudang PT. X. Jurnal prosiding Psikologi 2 (02), 592-596

Syamili, Putri. (2020). Hubungan Efikasi Diri Dengan Kepuasan Kerja Karyawan Di Pt.Pln (Persero) Area Yogyakarta. Skripsi. Yogyakarta: Fakultas Psikologi Universitas Ahmad Dahlan Yogyakarta

Tampubolon, Rugun, dan Hutagaol, Said.(2015). Hubungan Antara Efikasi diri dan etos kerja dengan kepuasan kerja guru SMAK penabur harapan indah kota Bekasi. Jurnal manajemen Pendidikan, 4(2), 187-204.

Yakin,M. \&Edril,O.(2012). Relationship between self efficacy and work engagement and the effects on job satisfaction: a survey on certified public accountants. Journal of social and behavioral scienceArdiani \& Mulyana. (2018). Hubungan Antara Efikasi Diri Dengan Kepuasan Kerja Pada Karyawan Bank Pembiayaan Rakyat Syariah. Jurnal penelitian Psikologi vol.5 no.2. 